\title{
Trade, infrastructure and income inequality in selected Asian countries: An empirical analysis
}

\author{
By \\ Ajitava Raychaudhuri* \\ Prabir De $e^{* *}$
}

\begin{abstract}
"Professor of Economics, Department of Economics, Jadavpur University (JU), Kolkata, India and ${ }^{* *}$ Fellow, Research and Information System for Development Countries (RIS), New Delhi, India. An earlier version of the paper was presented at the international workshop 'Trade, Investment and Regional Integration: Lessons for Policy Makers', organised by ARTNeT/ESCAP and the Ministry of Commerce \& Industry, Government of India, held at New Delhi, 1112 March 2010. Authors are grateful to one anonymous referee for insightful comments. Authors sincerely acknowledge the useful comments of Mia Mikic and workshop participants made on the paper. This paper was prepared as part of the ARTNeT initiative. The technical support of the United Nations Economic and Social Commission for Asia and the Pacific is gratefully acknowledged. The opinion figures and estimates are the responsibility of the author and should not be considered as reflecting the views or carrying the approval of the United Nations, ARTNeT, RIS and JU. Any remaining errors are the responsibility of the authors, who can be contacted at ajitava1@gmail.com and prabirde@hotmail.com, respectively.
\end{abstract}

The Asia-Pacific Research and Training Network on Trade (ARTNeT) is aimed at building regional trade policy and facilitation research capacity in developing countries. The ARTNeT Working Paper Series disseminates the findings of work in progress to encourage the exchange of ideas about trade issues. An objective of the series is to get the findings out quickly, even if the presentations are less than fully polished. ARTNeT working papers are available online at www.artnetontrade.org. All material in the working papers may be freely quoted or reprinted, but acknowledgment is requested, together with a copy of the publication containing the quotation or reprint. The use of the working papers for any commercial purpose, including resale, is prohibited. 


\section{Table of Contents}

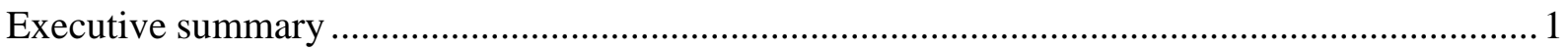

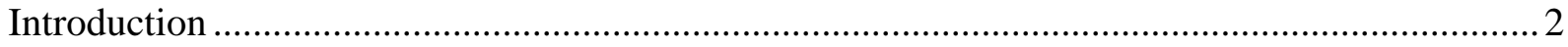

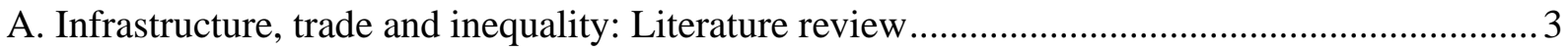

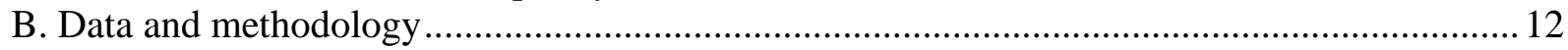

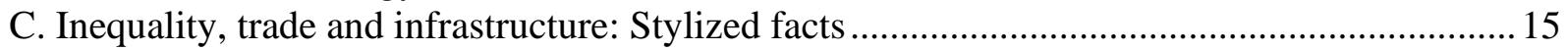

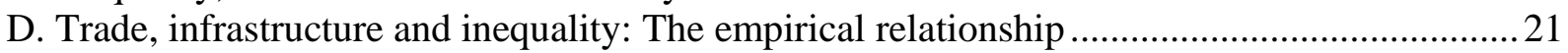

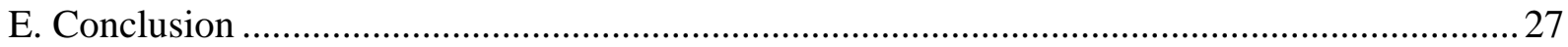

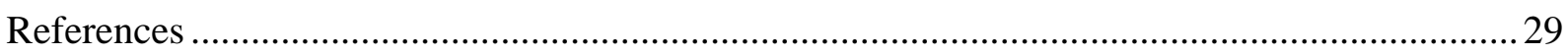

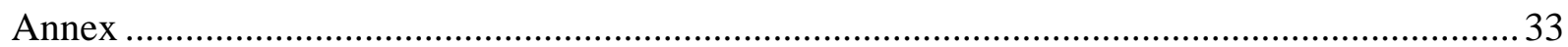

\section{List of figures}

Figure 1: How infrastructural development helps in poverty reduction ...................................... 11

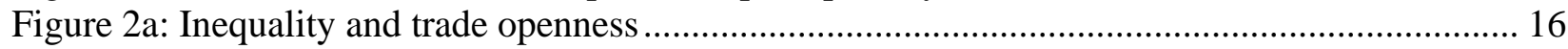

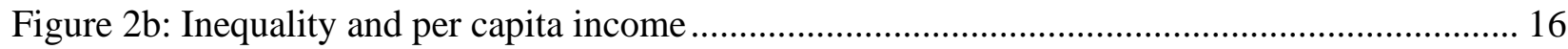

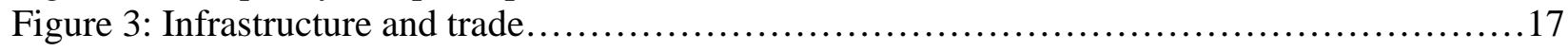

Figure 4: Trade openness and trade openness liberalization......................................................... 17

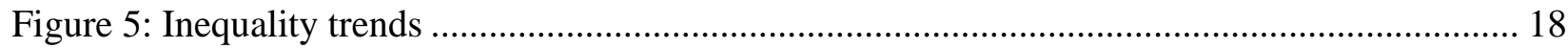

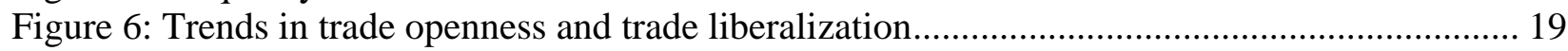

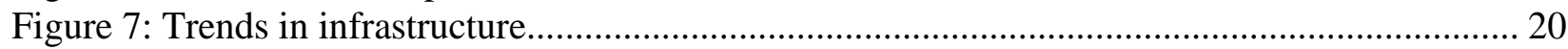

\section{List of tables}

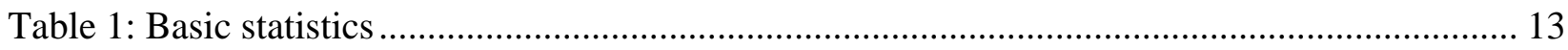

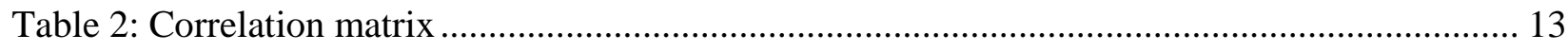

Table 3: Inequality, trade and infrastructure: Baseline regression results ...................................... 22

Table 4: Trade, Inequality and infrastructure: Baseline regression results ...................................... 24

Table 5: Arellano-Bover Dynamic Panel-data estimation (system GMM):

Dependent variable equals inequality (in Gini)............................................................................. 26

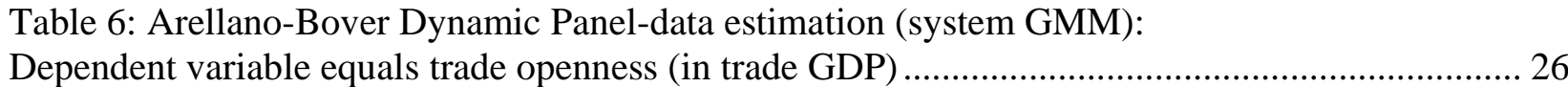




\section{Executive summary}

Theoretical and empirical works related to international trade are confined to models which have labour and capital as explicit factors of production. Although income inequality and trade openness have been given importance in the literature, the role of quantity and quality infrastructure has barely been investigated in this context. Similarly, growth regressions have highlighted the role of infrastructure and trade openness in economic growth, while inclusive growth has not received much attention.

This paper attempts to unravel the interlinkages and interconnections among infrastructure, trade openness and income inequality, using panel data of 14 Asia-Pacific countries at different levels of development. The empirical exercise clearly reveals influence of trade openness and infrastructure on income inequality but the reverse is not necessarily true. Moreover, countryspecific factors turn out to be important determinants of trade openness and income inequality. Further, dynamic panel estimates reveal importance of initial values of both income inequality and trade openness as important determinants in the evolution of these variables, apart from the positive influence of infrastructure as a determining variable. 


\section{Introduction}

The relation between trade, inequality and poverty within countries is not beyond controversy. Most international trade economists have a perspective of a world in which countries exchange goods, factors and ideas. Free trade in goods leads to equalization of factor prices across countries according to the factor-price-equalization theorem. In the traditional literature on neoclassical growth model, capital and labour play the central role as two main factors of production. From the perspective of conventional one sector neo-classical growth theory international linkages do not matter, but from the trade perspective they are the crucial determinants.

Under free trade and competitive conditions, trade promotes growth, and growth reduces poverty (Bhagwati and Srinivasan, 2003). In the literature on international trade, the issues of income distribution, growth as well as distortions are more or less discussed in terms of endowments of capital and labour, their growth and their relative prices. Countries that initially had a more regulated trade sector experienced an increase in inequality where trade reform, however, does not appear to have significantly affected changes in income distribution. ${ }^{1}$ In the income distribution literature, the functional distribution of the two major factors of production again explains the movement of inequality in income distribution over time. ${ }^{2}$ Although infrastructure plays the role of a very important catalyst, it gets virtually no explicit mention in the relevant literature on trade and inclusive growth. ${ }^{3,4}$

During the recent decades of globalization, economies in Asia and the Pacific grew rapidly until the ongoing global economic and financial crisis appeared in mid-2007. This acceleration of growth, in which international trade has played an important role, has helped Asian and Pacific countries to make impressive strides in economic development (ESCAP, 2009). At the same time, empirical evidence suggests that in some supply-constrained larger economies in Asia and the Pacific, such as China, India and Indonesia, prosperity through trade has been accompanied by rise in inequality. ${ }^{5}$ In fact, globalization in Asia and the Pacific has resulted in growing social and income inequalities. ${ }^{6}$ Thus, free trade is not necessarily a pro-poor growth strategy, where we take either the change in first order inequality as captured by the Gini coefficient, or the change in the number of people below a pre-specified poverty line.

There are compelling reasons why rising levels of inequality can slow down growth prospects when distortions affect different income groups unequally in Asia and the Pacific (e.g., the Lao People’s Democratic Republic vs. Thailand). Among other things, high levels of inequality can

\footnotetext{
1 There is strong literature on trade and income distribution supporting the fact that trade liberalization does not necessarily lead to equality of income in the presence of trade distortion. See, for example, Edwards, 1997, Slaughter, 1997.

${ }^{2}$ Refer, for example, Campano and Salvatore, 2007; Gourdon et al., 2008.

${ }^{3}$ However, development in endogenous growth theory has introduced the possibility of a productive role of public expenditure on infrastructure with an associated possibility of increasing returns to scale (Barro, 1990 and 1991).

${ }^{4}$ In economics, there is a need to concentrate on economic infrastructure, which includes services from: (a) public utilities, such as power, telecommunications, piped water supply, sanitation and sewerage, solid waste collection and disposal, and piped gas; (b) public works, such as roads, and major dam and canal works for irrigation and drainage; and (c) other transportation sectors, such as urban and inter-urban railways, urban transport, ports and waterways, and airports (World Bank, 1994). Also refer, Canning, 2006, and Straub, 2008.

${ }^{5}$ See, for example, Asian Development Bank, 2007.

${ }^{6}$ See, for example, ESCAP, 2001.
} 
have adverse consequences for social cohesion, quality of institutions and policies, and infrastructure. In turn, social divisions, low-quality institutions and policies, and a lack of infrastructure can have adverse implications for growth prospects of countries in Asia and the Pacific. Since the increases in income inequality can have important implications for the evolution of economic well-being in the long term, it is important to understand the present symptom of linkage, if any, between inequality, trade and infrastructure in developing Asian and Pacific countries. This paper attempts to provide a succinct answer to the debate on trade, inequality and infrastructure linkages. In addition, it deals explicitly with the recent literature aimed at bringing infrastructure to the forefront in the context of trade and inclusive growth.

Rest part of the paper is organised as follows. Section A presents a review of the literature on interconnections between infrastructure, trade and inequality. Section B provides the data and methodology. Section C presents stylized facts on infrastructure, trade and inequality in Asian and Pacific countries. The analytical results and possible implications are presented in section $\mathrm{D}$ and the conclusion is given in section $\mathrm{E}$.

\section{A. Infrastructure, trade and inequality: Literature review}

\section{Relationship between infrastructure and growth}

The role of infrastructure in promoting growth is perhaps the most discussed topic as far as the role of infrastructure in the economy is concerned. The linkage between infrastructure and economic growth is multiple and complex, because apart from affecting production and consumption directly, it creates many direct and indirect externalities, and involves large flows of expenditure thereby creating additional employment (Ghosh and De, 2005). Estache (2006) pointed out that since the late 1980s, more than 150 published papers in English, French, or Spanish had analysed the macroeconomic effects of infrastructure. This literature, with regard to infrastructure, has mainly resulted from conceptual and technical developments associated with new growth theory and new economic geography. According to Estache, the most common way of estimating the impact of infrastructure on growth is to calculate the social rates of return of investment in various types of infrastructure. The methodology used - i.e., growth regressions - is quite common. The findings of the regressions are quite significant as they suggest that in recent years economic returns on investment projects have averaged between 30 per cent and 40 per cent for telecommunications, more than 40 per cent for electricity generation and more than 200 per cent for the construction of new roads. (However, when the outliers are excluded, the average is about 80 per cent for roads.) It was also found that returns tend to be higher in low-income countries than in middle-income countries (Estache, 2006). Thus the conclusion is that infrastructure has a very strong impact on the growth process of a nation, especially if it is a low-income country.

Change in public capital structure is one important factor affecting the long-term behaviour of a country. The decline in United States' productivity was preceded by lower infrastructure investment (Munnell, 1992). Aschauer (1989), while discussing productivity slowdown in the United States, argued that (a) public physical capital together with private and human capital are crucial inputs in the steady state production function; (b) the means of financing public capital 
affects the level of productivity; and (c) efficiency of use of public capital together with the quantity of public capital are crucial determinants of the effective public capital stock. He also found that one percentage point increase in the efficiency of public capital increased transitional growth by 0.29 percentage points, while a rise in the debt-financed public capital reduced growth rate by 0.25 per cent. Thus, the quality of public capital, which incidentally in the United States' context points to infrastructure, plays a very important role in increasing the growth rate of the economy as long as it is not counter-balanced by external debt.

Similar research by Hulten (1996) places greater stress on the quality of public capital or infrastructure capital. He defined effective public capital as $K_{g}{ }^{e}=\theta K_{g}$, where $\theta$ measured the degree of efficiency in the use of public capital. He used four different indicators to quantify the performance of public capital, i.e., faults in 100 telephone mainlines, satisfactory paved roads as a percentage of total roads, electricity generation losses to total, and the percentage of diesel locomotives to total rolling stock for transportation. He aggregated them into one performance index and then used data for 46 low- and middle-income countries in the period spanning 1970 to 1990. The regression used is real GDP growth per capita on infrastructure performance index, private investment and human capital. The output elasticity to infrastructure, which includes the efficiency term, shows variability ranging from 0.009 to 0.244 , indicating that countries using infrastructure more efficiently attained much faster growth of per capita real GDP. More explicitly, his comparison of four East Asian fast-growing countries with 17 African countries showed that had the African countries used infrastructure at the same level of efficiency as the East Asian countries, their growth rates per annum would have been 0.75 per cent rather than -0.20 per cent, which is the actual recorded growth.

Thus, the above results point to the importance not only of the amount of public capital embodied mainly in infrastructure but also its effective use. High levels of public spending per se do not promote rapid growth. The performance of such capital is the main variable promoting faster growth. As Hulten (1996) found, public capital does not influence the growth of low- and middleincome countries very much; it is the effectiveness index that influences it decisively. Aschauer's later study (1998) supported the same conclusion. This points to the basic premise that total factor productivity has a close positive relationship with the performance of the infrastructure capital.

Briceño-Garmendia, Estache and Shafik (2004) highlighted the importance of infrastructure in developing countries unlike its impact on developed countries. They noted that of about 102 studies conducted during the past 15 years, few had found that infrastructure investment had a negative effect on productivity or growth. The sample included 30 studies of multiple countries (including developing countries), 41 studies of the United States, 19 of Spain, and 12 of individual developing countries (Argentina, Brazil, Colombia, India and the Philippines). As stated above, unambiguous results were found in the developing country studies. According to those results, the role of infrastructure is more prominent in the developing countries. Thus, infrastructure does not present any perverse signal for economic growth of any developing country.

A note of caution was sounded in this context by Roland-Holst (2006) who argued infrastructure and growth had causation in both directions, and failure to consider this factor would thus result in overestimation of the contribution of infrastructure to growth. In fact, Calderón and Servén (2005) presented an empirical analysis focusing on Latin America. They reported positive 
and significant output contributions of three types of infrastructure assets, i.e., telecommunications, transport and power. Fedderke, Perkins and Luiz (2006) attempted to explain the relationship between investment in economic infrastructure and long-term economic growth by examining the experience of South Africa in a time-series context. Their results indicated that infrastructure had both a direct and an indirect impact on output, and that it may have had an important role in pushing the country onto a higher long-term growth trajectory.

\section{(a) Infrastructure and inclusive growth}

The above discussion provides an overview of the interconnection of infrastructure with growth. But as already emphasized, a strong positive influence by infrastructure on economic growth does not necessarily ensure inclusive growth. The discussion of inclusive growth can move in several directions, but the literature discusses this either in terms of access and affordability of, and access to, infrastructure by the poor or the effect of infrastructure on income distribution. The concept of inclusive growth is used interchangeably with the concept of pro-poor growth defined above. This section deals specifically with this pro-poor growth aspect..

Brenneman and Kerf (2002) argued that infrastructure expanded education (especially for transport and energy services), and positively affects health outcomes (especially for the water/sanitation, energy and transportation sectors), but that it was not that visible in telecommunications. Ravallion and Datt (1999) found that between 1960 and 1990 rural poverty levels changed considerably in Indian States. Their results showed that non-farm economic growth was less effective in reducing poverty in those States with "poor" initial conditions in terms of rural development and human resources. They explained that factors such as low farm productivity, low rural living standards relative to urban areas as well as poor basic education resulted in the poor not participating fully in the growth of the non-farm sector. Deninger and Okidi (2003) reported similar findings regarding growth and poverty reduction in Uganda during the 1990s. Their work indicates the importance of improving access to basic education and health care. At the same time, this paper points out the dependence of social infrastructure on complementary investments in electricity and other infrastructure.

Ghosh and De (2005) carried out a detailed study on the role of infrastructure in exacerbating the inter-state inequality in India. They took data for 18 major Indian States for the period of 197071 to 1999-2000. They regressed the real per capita State GDP on several social, financial and physical infrastructure variables. This study indicated that:

(a) Inter-state disparity in per capita net State domestic product among Indian States has been rising significantly during the past 25 years;

(b) Inter-state disparities in physical, social and financial infrastructure facilities have remained at an alarmingly high level during the same period. That is, the relative positions of the States have remained unchanged in terms of any definition of development. In other words, there have been enormous differences in individual performance among the Sates in terms of all the basic indicators of development;

(c) Physical and social infrastructure facilities have proved to be highly significant factors in determining the inter-state level of development. 
Ghosh and De's (2005) conclusions support the findings of Ravallion and Datt (1999). Hence, inclusive growth requires a balanced development of infrastructure across regions so that growth is evenly spread across rich and poor States over time. However, to overcome the initial imbalance, the poorer regions need more accelerated investment in infrastructure as revealed in the case of the Indian States.

Khandker and Koolwal (2006) analysed the impact of infrastructure development on propoor growth in context of Bangladesh. Using quantile regression techniques, they concluded that growth in overall income indeed led to a significant reduction in poverty, and that it had had a significantly higher impact on extreme poverty reduction compared with moderate poverty reduction. They argued that while those pure growth effects on household poverty incidence were not very large, income growth through certain policies - i.e., proximity to roads, electrification and commercial bank penetration - could lead to substantial reductions in overall poverty in the sample. This is an important observation that investment on specific infrastructure produces welfare enhancing distributional effect compared to pure growth.

In a similar paper, Khandker, Bakht and Koolwal (2006) revealed the importance of rural roads in Bangladesh. Again, using panel quantile regression, they found that in road development project (RDP) areas, both moderate and extreme poverty declined in project villages. In those villages, about 57 per cent of households were moderately poor before the road was paved, while some 48 per cent of households were poor after the road had been paved. A reduction of about 6 per cent in extreme poverty (from 35 per cent to 29 per cent) was registered in RDP project villages after roads were paved. Interestingly, they found that in control villages there was no significant change in poverty over time.

These results are very similar to the findings of Binswanger, Khandker and Rosenzweig (1989), who highlighted the importance of roads in India's rural economy. They said it worked through marketing and distribution scopes, and through reduced transportation costs for agricultural goods. Somewhat complementary to this are the findings of Barnes and Binswanger (1986) regarding the effect of rural electrification on agricultural productivity in India.

Fan, Zhang and Zhan (2002) documented the critical role of infrastructure development in China. Using Chinese provincial data for 1970 to 1997, the simultaneous equations model indicated that government investment in irrigation, education and infrastructure (particularly roads, electricity and telecommunications) not only helped in raising growth levels but also contributed significantly to the reduction of rural poverty and regional inequality in China. They showed that this happened mainly because of the increased opportunity for rural non-farm employment that followed expansion of infrastructure. They pointed out that in 1997, although 69 per cent of people lived in the rural areas, rural investment was only 21 per cent of total investment, leading to a larger rural-urban gap. Similar to the findings for India and Bangladesh, rural roads had the highest impact on rural poverty reduction in China.

Jacoby (2000) found a somewhat discordant note in his research on Nepal. He showed that extending road access to the entire rural population of Nepal would raise average income by about 10 per cent. The benefits of rural roads are lower costs for transporting crops to market and obtaining modern inputs such as fertilizer. Although many of these benefits would go to the poor, 
who tend to live in the more remote areas, the benefits are not large enough to make big progress in poverty alleviation. Part of the reason for this is that the primary beneficiaries of infrastructure projects are landowners, who are typically not poor. This is a disturbing finding in the sense that rural roads increase income and accelerate rural growth but do not promote inclusive growth in a poor country such as Nepal. Jacoby further stated that new road construction directly benefited landowners by raising the value of their land, while landless households that supply farm labour were unlikely to benefit at all.

He found that wages were lower in the more remote rural areas of Nepal - half a percentage point lower for a 10 per cent increase in travel time. However, the lower wages in more remote areas are probably offset by the lower cost of living. Road construction would therefore have little net benefit from the perspective of the landless household, since any increase in wages would be accompanied by a rise in the cost of living. Therefore, a critical look must be taken at the infrastructural investment in the context of inclusive growth.

Calderón and Servén (2005) delved into both the growth and the inequality aspects of infrastructure investment. They provided an empirical evaluation of the impact of infrastructure development on economic growth and income distribution, using a large panel data set encompassing more than 100 countries and spanning 40 years (1960-2000). With regard to infrastructure and income inequality, they concluded that availability and quality of infrastructure services for the poor in developing countries had a significant positive impact on their health and/or education and, hence, on income and welfare.

Calderón and Servén (2005) also dealt with the issue of private participation in infrastructure investment by examining how large an increase, if any, there was in its pro-poor effect. They considered the important aspect of distributive impact of private participation in infrastructure, which had attracted considerable attention and which involved both macro and microeconomic linkages. One important macro effect is that concerning employment and the major controversy of whether private participation will lead to downsizing and a subsequent decline in employment. According to Calderón and Servén, "the distributive impact of downsizing depends on the access of lower income segments of the population to public sector employment in infrastructure, and on the monetary compensation [paid] to workers who are laid off for efficiency reasons. If the investment by the newly reformed providers of infrastructure promotes growth and new jobs, the process of job destruction in the public sector may be offset by the creation of employment in other sectors." The micro impact may be a sectorwise withdrawal of subsidies after private participation, which might make access to infrastructure quite difficult for the poor.

A recent World Bank Independent Evaluation Group (IEG) (2008) review of World Banksponsored electrification schemes found a pro-rich bias in the rural electrification schemes. The report first identified the number of schemes promoted by the World Bank in past 28 years. The report then went on to highlight the fact that the poor had not benefited much from these schemes. It pointed out that a high rate of rural electrification did not guarantee that the poorest and those living in fringe areas of the rural sector would benefit from that type of electrification.

Raychaudhuri (2004) discussed the role of rural roads in the context of agricultural productivity growth as well as poverty reduction in the State of West Bengal in eastern India, which 
had one of the highest levels of rural poverty in the country during the early 1970s. West Bengal saw two major turnarounds in the rural sector from the 1980s: (a) a spectacular jump in the growth rate of production of rice, from 1.8 per cent during 1960-1980 to 4.68 per cent from 1977 to 1994; and (b) a remarkable fall in the rural poverty level, from 73 per cent in 1973 to 31 per cent in 1999. In fact, on both counts, West Bengal surpassed the achievements of other States substantially.

At the same time, budget surveys showed much heavier dependence among the population on food items (dominated by rice consumption) in West Bengal (65.9 per cent) compared with the Indian average (59.4 per cent) in 1999-2000. The rural population earned the maximum from rice production since it occupied 84.87 per cent of total food-grain area in 1980-1981 and 90.62 per cent in 1999-2000. Thus, a rise in agricultural productivity for the monsoon rice crop, which is practiced most by the poor farmers, helped to raise income levels as well as expand consumption possibility set of poor farmers.

Raychaudhuri (2004) attempted to use several explanatory variables to explain the change in agricultural productivity of monsoon rice crops. Apart from some land reform-related variables, rural roads maintained by the local level administration happened to be the variable that had the greatest influence on agricultural productivity of such crops. The reason was that better connectivity helped the farmers to sell their surplus crops in time as well as procure necessary inputs with relative ease. Thus, it not only helped the growth of agriculture but also directly assisted the reduction of poverty among small farmers.

In an interesting study, Rodriguez (2006) attempted to understand the role of infrastructure in growth and the divergence of the rich and poor States around the world. He noted that the growth scenario was accompanied in many cases by a falling infrastructure stock. Thus, although infrastructure stock has been found to be a significant variable that influences growth, it may also have caused divergence among the developing countries. Rodriguez (2006) reviewed the empirical evidence supporting the assertion that the collapses in infrastructure investment that occurred during the 1980s and 1990s in many developing countries was a major force behind growing disparities in world incomes. While it is argued in this paper that the empirical evidence supports the existence of a positive effect of infrastructure provision on productivity and growth, Rodriguez (2006) found little evidence that the retrenchments in infrastructure provision had played a major role in growing disparities. He stated that the basic reason was because most developed countries also experienced a deceleration in their accumulation of infrastructure stocks during those periods, allowing some developing countries to catch up and others to avoid falling behind in terms of infrastructure provision. Therefore, the conclusion to be drawn from this finding is not to neglect the infrastructure in any economy so that countries can maintain both the tempo of work and parity with fast-growing countries.

A different line of thought can also be found in Songco (2002), who discussed the importance of community perception based infrastructural development in the context of rural Viet Nam. In many cases, rural communities in that country had failed to grasp the direct benefit of infrastructural investment. Songco suggested that in such cases the complementarity of investments in infrastructure capital should be recognized. Songco noted that the rural poor interviewed in Viet Nam appreciated road improvements in their communities; yet, they were also able to suggest initiatives in other areas for improving household welfare, such as expanded credit opportunities for 
the poor, and improvement of existing services, such as increased staffing at already established local health centres. The new Community-Based Rural Infrastructure Project in Viet Nam is one example of a project that seeks to enable community-driven infrastructure selection to reduce rural poverty. Attention is needed to ensuring that the rural poor (as opposed to simply the rural non-poor) are duly consulted and involved in planning and decision-making in a meaningful way.

\section{Infrastructure, trade and inequality}

As pointed out in the beginning of this paper, the neo-classical as well as new trade theories rely heavily on a two-country, two-factor and two-goods model (the 2x2x2 model). Thus, infrastructure appears mainly as a complementary factor that facilitates trade. This will be visible in one of the two following ways: (a) it has a strong positive influence on trade volume (Deardorff, 2001a, 2001b), or (b), it might influence trade cost (Anderson and van Wincoop, 2004).

Infrastructure might influence trade cost more than tariff and non-tariff barriers, but measurement is probably more difficult. Infrastructure is a composite term measured as an average of the density of the road network, the paved road network, the rail network and the number of telephone main lines per person. The supposed impact of tariff and non-tariff barriers may be less in magnitude compared to inefficiency-related and enforcement-related costs of infrastructure. Although it is difficult to measure it accurately and directly, according to Limao and Venables (2001) trade costs depended heavily on infrastructure. They gathered price quotes for shipment of a standardized container from Baltimore to various points in the world and found that a deterioration of infrastructure from the median to the 75th percentile of destinations raised transport costs by 12 per cent. A similar conclusion was reached in the studies undertaken by the Asian Development Bank Institute, which showed that port infrastructure was the most important factor in the reduction of trade costs for Asian countries, given the preponderance of sea freight in trade costs for Asian countries (De, 2007, 2009a; Brooks and Hummels, 2009)

Pinstrup-Andersen and Shimokawa (2006) argued that insufficient domestic rural infrastructure was a major bottleneck to achieving the potential benefits from international trade liberalization and other aspects of globalization. This point is illustrated by China's recent experience. They emphasized that poor infrastructure was one of the major reasons for the slow growth of exports from African countries. In fact, they noted that India's road density in 1950 was four to five times higher than that of many African countries in 1990. They found that low transport costs due to good infrastructure would have increased price and non-price competitiveness of products from African countries in addition to attracting foreign direct investment, which is vital for the betterment of infrastructure.

Although an Organisation for Economic Co-operation and Development (2003) study on trade facilitation dealt mainly with the World Trade Organization (WTO) definition of borderrelated trade transaction costs, it made the following interesting observations. After analysing border process quality across 102 countries it found that those countries with a higher per capita income generally scored better with regard to border process quality than countries whose inhabitants were less well off. However, some countries that were not particularly well off exhibited better border processing. The study concluded that low-income countries did not necessarily have to wait until they became rich before being able to adopt good border practices. In other words, poorer countries 
can also show efficiency and need not be written off as having little likelihood of being able to compete with the richer nations in terms of price and non-price competition.

While dealing with the Indian case, Acharyya (2008) argued that the growth impact of trade had remained weak from 1985 to 1999 . He argued that urban poverty in India had declined and income inequality had increased significantly during the 1990s, when some policy changes with regard to trade and exchange rates had been implemented.

Winters, McCulloch and McKay (2004) summarized a number of studies that discussed the role of trade liberalization in poverty reduction. Their survey indicated that although trade liberalization might work through many channels, the outcome depended on a number of factors, including the starting point of reform, the precise trade reform undertaken, the characterization of the poor and the way they sustained it. They emphasized that one of the survey's main results showed that the poor might enjoy less benefits of trade reform than their richer counterparts. Hence, trade policy needs to be complemented by other policies, one of which may well be (or may result in) better access to infrastructure by the poor. Figure 1 highlights some of the points raised, including the fact that infrastructure development helps in the reduction of rural poverty through various channels. 
Figure 1: How infrastructural development helps in poverty reduction

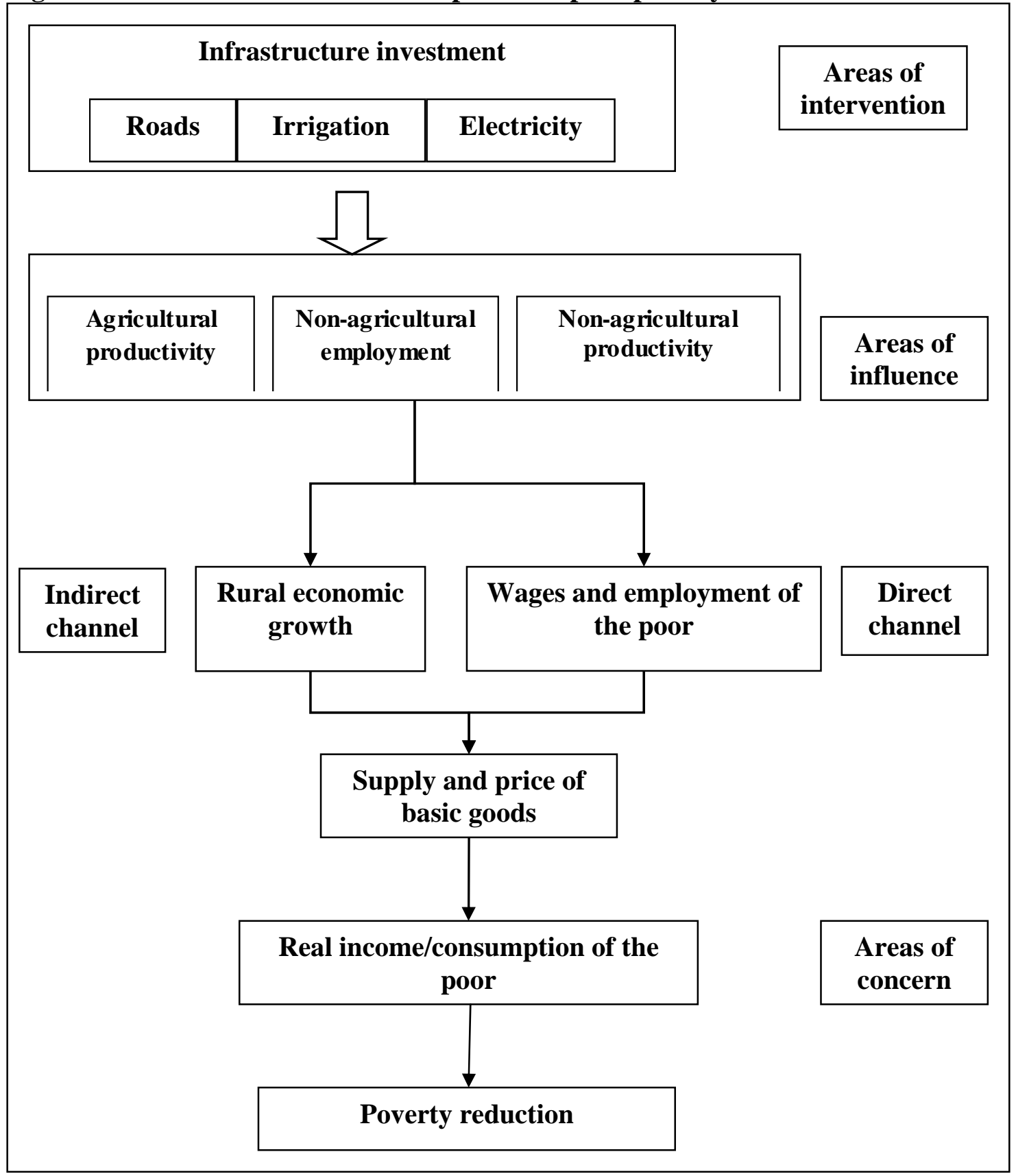

Source: Ali and Pernia, 2003.

Figure 1 shows the linkage between infrastructure and poverty reduction. It should be noted that while a reduction in income inequality may reflect a strong poverty reduction programme in a country, this is not a necessary condition. The trade costs throw an additional dimension to this. The link between trade, infrastructure and income inequality as well as poverty reduction can be explained in terms of how far the lack of infrastructure might affect small and unorganized producers in developing countries. This is crucial as trade might promote inequality since a number of small producers may not be able to take part in a liberalized trade regime due to lack of 
infrastructure. As figure 1 shows, roads, electricity and irrigation are key factors that increase agricultural and non-agricultural productivity and employment. If the international trade dimension is taken into account, freight carried by sea and air as well as tele-density can be added to this list of infrastructural facilities. However, this also creates the possibility of unequal access to these facilities, since large-scale farmers and non-farm producers could take much greater advantage of these factors than could small-scale farmers and non-farm producers.

Datt and Ravallion (1998) discussed the role of social infrastructure in enabling some States in India to reduce rural poverty faster than others. For example, Kerala State reduced rural poverty the fastest and had the highest literacy levels among men and women in the whole of India. This helped Kerala to export skilled workers - even from poorer rural households - it is out-migration mainly to the Gulf region. This generated a huge inflow of remittances from abroad, which is a key driver of raising income levels among the rural poor. Trade is therefore not confined to goods, but also encompasses international factor movements, which play a key role in the reduction of poverty as is clear from the case of Kerala.

Raychaudhuri and De (2010) analysed the impact of increased trade in services in India on inequality. They found that one major component of India's service sector growth comprised information and communication technology (ICT) services. The study showed that the ICT sector led the service trade in India. However, the sector is skill and infrastructure intensive. The major IT and IT-enabled services are located in big metropolitan cities. As a result, the sector does not support unskilled workers nor has it made its presence felt in the rural areas. Thus, this type of increase in services trade has increased the inequality within the urban regions of India as well as greater income divergence between rural and urban incomes.

\section{B. Data and methodology}

To understand the interconnection and interdependence between trade, inequality and infrastructure, cross-country panel data regressions are a common technique used by many researchers, as noted in section A. Hulten (1996) used panel regressions to show the importance of quality of infrastructure to growth, which incidentally has a large number of countries taken from all parts of the world for growth rate in 1990 over 1970. Datt and Ravallion (2002) used an unbalanced panel fixed-effect regression to understand the reduction of poverty in different States in India that was caused by several infrastructural variables. Pinstrup-Andersen and Shimokawa (2006) described a number of studies that used panel data regressions as well as simultaneous regression models to study the impact of infrastructure on agricultural productivity. An excellent analysis comparing different cross-country dynamic panel data estimates, with more standard pooled OLS and fixedeffect estimates for measuring impact of infrastructure on growth, was carried out by Calderón and Servén (2005).

A good discussion of the technicality of a number of such studies can be found in Levine and Renelt (1991), which is mentioned below in this section. The authors of this paper carried out an Asian cross-country study on the same issues, using data from 14 Asian countries: Bangladesh; 
China; Hong Kong, China; India; Indonesia; Republic of Korea; Malaysia; Nepal; Pakistan; Philippines; Singapore; Sri Lanka; Thailand; and Viet Nam. ${ }^{7}$

Table 1: Basic statistics

\begin{tabular}{|c|c|c|c|c|c|}
\hline Variable & Obs & Mean & Std. Dev. & Min & Max \\
\hline $\begin{array}{l}\text { Inequality (INQ), represented by Gini } \\
\text { coefficient }\end{array}$ & 120 & 39.82 & 6.69 & 23.20 & 53.10 \\
\hline $\begin{array}{l}\text { Trade openness (TO), represented by } \\
\text { trade-GDP ratio }\end{array}$ & 120 & 100.53 & 104.95 & 9.69 & 476.78 \\
\hline Infrastructure stock (IS) & 120 & 3.97 & 1.21 & 2.50 & 7.14 \\
\hline $\begin{array}{l}\text { Infrastructure quality (IQ), represented by } \\
\text { transmission and distribution losses in } \\
\text { electricity }\end{array}$ & 120 & 12.93 & 7.62 & 2.41 & 35.62 \\
\hline Per capita income (PCI) & 120 & 4010.54 & 6893.20 & 142.39 & 32250.00 \\
\hline $\begin{array}{l}\text { Geography (Land), represented by per } \\
\text { capita availability of land }\end{array}$ & 120 & 5.62 & 4.80 & 0.15 & 26.19 \\
\hline Inflation (Inf) & 120 & 6.23 & 5.49 & -17.63 & 24.56 \\
\hline Population (Pop) & 120 & 62.66 & 6.18 & 52.45 & 73.17 \\
\hline
\end{tabular}

Table 2: Correlation matrix

\begin{tabular}{lcccccccc}
\hline & INQ & TO & IS & IQ & PCI & Land & Inf & Pop \\
\hline INQ & 1 & & & & & & & \\
TO & $0.3981^{*}$ & 1 & & & & & & \\
IS & 0.1499 & 0.0821 & 1 & & & & & \\
IQ & -0.1067 & $-0.5372^{*}$ & -0.0935 & 1 & & & & \\
PCI & $0.2670^{*}$ & $0.8778^{*}$ & 0.1316 & $-0.4877^{*}$ & 1 & & & \\
Land & 0.0473 & $-0.3533^{*}$ & $0.2216^{*}$ & -0.0343 & $-0.4442^{*}$ & 1 & & \\
Inf & -0.0900 & $-0.2794^{*}$ & $-0.2274^{*}$ & $0.2140^{*}$ & $-0.3619^{*}$ & 0.1327 & 1 & \\
Pop & 0.0813 & $0.6363^{*}$ & 0.1222 & $-0.6840^{*}$ & $0.6595^{*}$ & $-0.3418^{*}$ & $-0.3368^{*}$ & 1 \\
\hline
\end{tabular}

Note: *Significant at the 5 per cent level.

While the annex provides the definitions of variables and sources, some basics about these variables are presented here. Table 1 shows that inequality (represented by the average Gini coefficient) is quite large at 39.82 and has a range of 23.20 to 53.10. Trade openness (represented by total trade [export + import] as a percentage of GDP) has an average value of 100.53 per cent but has a large variation as given by a standard deviation of 104.95. The infrastructure stock has an average of 3.97 with a range of 7.14 to 2.50 . Infrastructure quality (represented by electric power distribution losses as a percentage of output) stands at an average value of 12.93 per cent, with a range from 2.41 to 35.62 per cent. The control variables, with the exception of PCI, do not have much variation, as shown by their respective standard deviations. There is therefore a remarkable disparity between the prosperous and poor Asian countries in terms of per capita income and trade openness.

However, there is a strong correlation between some of these variables (table 2). Trade openness and per capita income are two variables that are highly correlated between themselves as

\footnotetext{
${ }^{7}$ The chosen set contains both LDCs and developing Asian countries since their per capita GDPs - in constant US dollar prices in 2000 - range from US\$142.39 to US\$21,322.16, from 1971 to 2006.
} 
well as with the population. As the population variable is not correlated with infrastructure stock, they can be used together. Similarly, infrastructure stock is not highly correlated with infrastructure quality, so they can also be paired in a panel regression. Although Levine and Renelt (1991) suggested that collinearity among the independent variables showed a weak dataset and that "extreme bound" analysis would show how truly independent a variable is, this problem of multicollinearity precludes the use of the full set of regressors.

The following equation was used to explore the relationship of inequality with trade openness and infrastructure:

$$
I N Q_{i t}=\alpha+\beta_{1} T O_{i t}+\beta_{2} I S_{i t}+\beta_{3} I Q_{i t}+\sum_{l} \delta_{l} Z_{i t}+e_{i t}
$$

where $I N Q$ is inequality measures (represented by the Gini coefficient), $T O$ is trade openness (represented by trade-GDP ratio), $I S$ represents physical infrastructure stock, $I Q$ is infrastructure quality (represented by transmission and distribution loss in electricity), $Z$ is the set of control variables, and $e$ is the error term. Here, $i$ represents country and $t$ is the time period. To control for country-level heterogeneity, country dummies were introduced into equation (1). The use of country fixed-effects considerably reduces the variance in inequality to be explained and the measurement errors therein. ${ }^{8}$ The final estimable equation is:

$$
I N Q_{i t}=\alpha_{0}+\alpha_{i}+\beta_{1} T O_{i t}+\beta_{2} I S_{i t}+\beta_{3} I Q_{i t}+\sum_{l} \delta_{l} Z_{i t}+e_{i t}
$$

While equation (2) provides the stochastic relationship of inequality with trade openness and infrastructure, it does not indicate the functional relationship of trade openness with inequality and infrastructure. Therefore, to explore the reverse relationship and specifically the relationship of trade with trade openness and infrastructure, the following equation was used:

$$
T O_{i t}=\alpha_{0}+\alpha_{i}+\beta_{1} I N Q_{i t}+\beta_{2} I S_{i t}+\beta_{3} I Q_{i t}+\sum_{l} \delta_{l} Z_{i t}+e_{i t}
$$

An unbalanced panel data has been created from the above. The problem is that the data are driven largely by the availability of information on inequality and infrastructure variables. The difficulty with the inequality data is that although the World Income Inequality Database (WIID) quotes from a variety of sources, there is a major problem with compatibility. ${ }^{9}$ The data have been sorted in such a way that they reflect the overall inequality of gross income of a country. An additional problem was the availability of multiple values for one year. The WIID database ranks each study in terms of its reliability. The authors were largely guided by that ranking, but if one figure looked like another, it was not used. The data on infrastructure variables also posed a time series continuity problem, which precluded the use of some variables such as paved roads, telephone main lines, railway freight and route $(\mathrm{km})$, education and health-related statistics etc. As a result, the study could not do proper justice to qualitative variables, as emphasized by Hulten (1996). The number of years in this study is much more but the countries under consideration are much less.

\footnotetext{
${ }^{8}$ In the case of the fixed-effect model, the Least Square Dummy Variable (LSDV) technique was used. The result establishes the fact that those country-specific effects not explicitly mentioned are significant, and clarifies the movement of the explained variable in addition to the common explanatory variables that are taken for each country.

${ }^{9}$ UNU-WIDER World Income Inequality Database, Version 2.0c, May 2008.
} 
Thus, the final estimable model could not accommodate all the variables the authors would have liked to have included. However, the authors attempted to utilize the best possible dataset, but the multi-collinearity problem precluded simultaneous use of some of the variables even within this reduced set.

\section{Robustness checks}

The relationships described above cannot be interpreted as causal until the possibility of endogeneity has been ruled out in equations (2) and (3). To address this problem, a dynamic GMM estimator (system-GMM) - also known as Arellano-Bover/Blundell-Bond linear dynamic panel-data estimation, - was used to analyse changes across countries and over time. ${ }^{10}$ The estimator also effectively deals with reverse causality by including lagged dependent variables to account for the persistence of the inequality and/or trade openness indicators. ${ }^{11}$

One of the main advantages of the system-GMM estimator is that it does not require any external instruments other than the variables already included in the dataset. It uses lagged levels and differences between two periods as instruments for current values of the endogenous variable, together with external instruments. More importantly, the estimator does not use lagged levels or differences by itself for the estimation, but instead employs them as instruments to explain variations in infrastructure development. This approach ensures that all information will be used efficiently, and that focus is placed on the impact of regressors (such as trade openness) on inequality, and not vice versa.

The reason the cross-country regressions technique was chosen for this study was because it was the methodology used by most of the papers discussed in section B to gain generalizations in the results. Thus, although it is true that few of the country-specific policies and variables (some of them do not vary much over time) may lead to movements in trade and inequality, the cross-country regression generalizes the result, focusing on some important accepted variables that are significant determinants. This in itself is important. Also, the fact can be established that country specific variables, together with the commonly accepted variables mentioned above, are indeed important catalysts in this analysis.

\section{Inequality, trade and infrastructure: Stylized facts}

The scatter diagram of inequality with trade openness, per capita income and infrastructure stocks for 14 Asia-Pacific countries in a panel of 1975 to 2006 shows that inequality is positively associated with all of them (figure 2). Trade in countries of Asia and the Pacific as well as rising per capita income have been associated with higher inequality. Figure 2c suggests that infrastructure stock in Asian and Pacific countries generated inequality, albeit at a lower magnitude, compared

\footnotetext{
${ }^{10}$ First introduced by Arellano and Bond, 1991.

11 Following Arellano and Bover, 1995, and Blundell and Bond, 1998, a system-GMM was taken in place of a difference-GMM. Arellano and Bover (1995) and Blundell and Bond (1998) revealed a potential weakness of the difference-GMM estimator. They showed that lagged levels can be poor instruments for first-differenced variables, particularly if the variables are persistent. In their modification of the estimator, they suggested the inclusion of lagged levels along lagged differences. In contrast to the original difference- GMM, they termed this the expanded estimator system-GMM.
} 
with trade openness. Trade openness and infrastructure stock, however, show a positive correlation, suggesting that infrastructure underpins trade openness (figure 3), whereas trade openness in the region is driven by trade liberalization with high tariffs in the initial years (figure 4).

Figure 2a: Inequality and trade openness

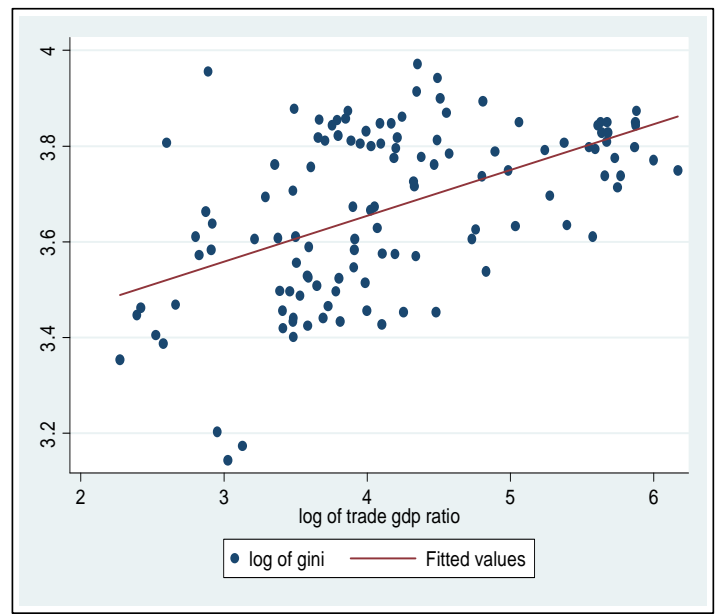

Figure 2b: Inequality and per capita income

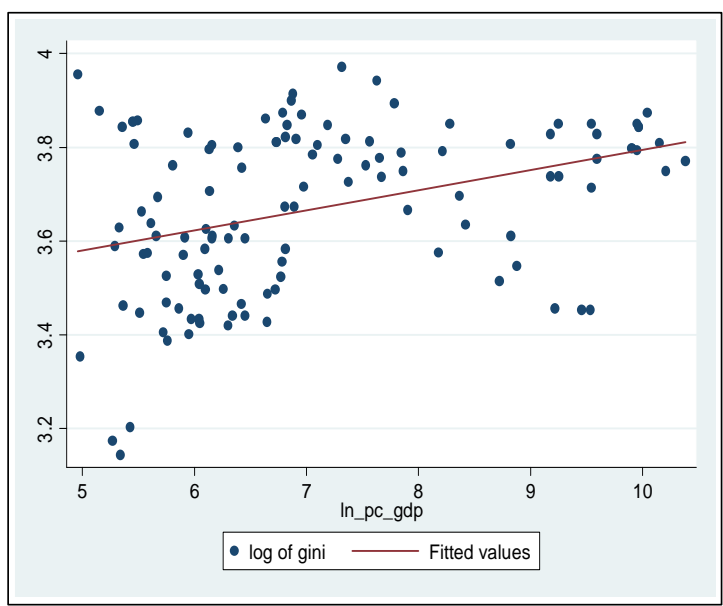

Figure 2c: Inequality and infrastructure

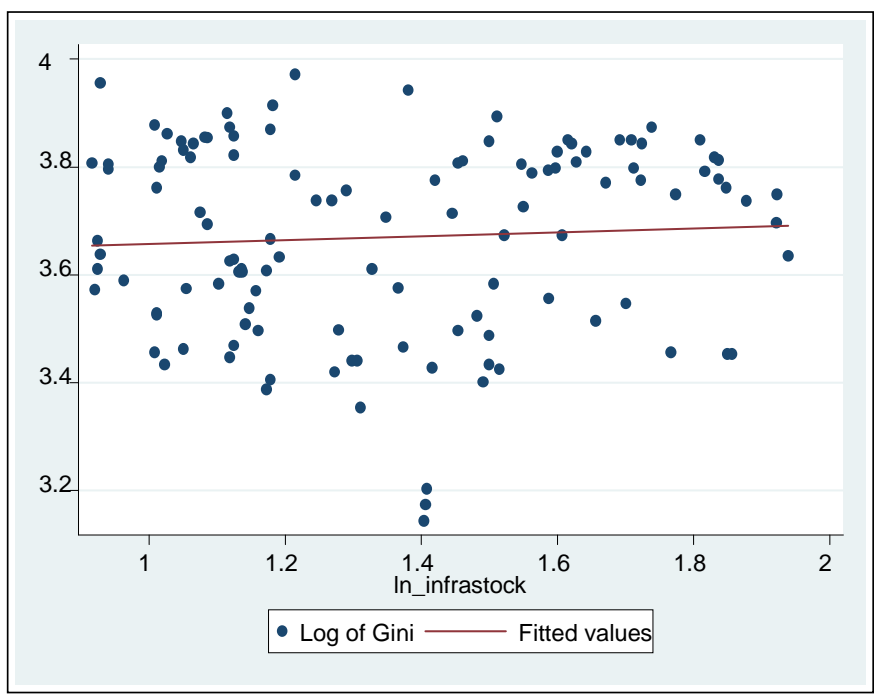


Figure 3: Infrastructure and trade

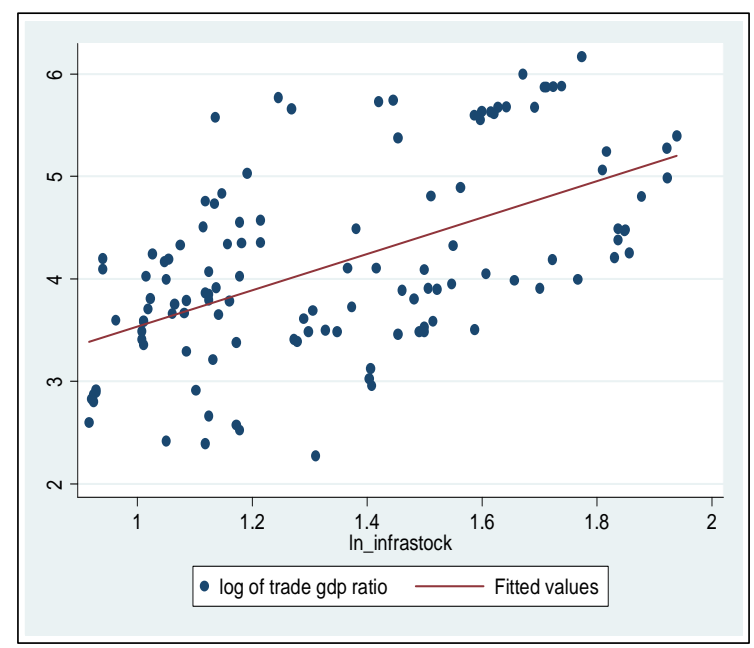

Figure 4: Trade openness and trade openness liberalization

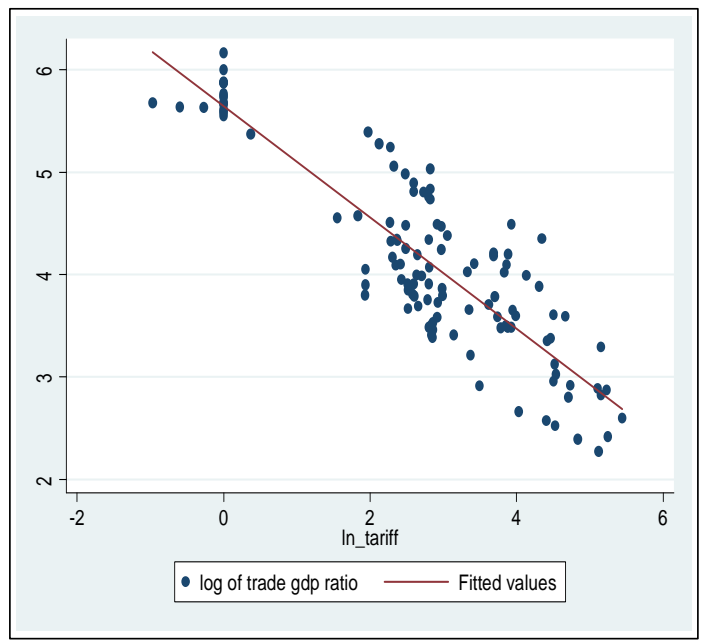

Therefore, it can be concluded that given all other things are constant, Asian and Pacific countries have experienced an increase in inequality. Three important observations in this discussion follow. 
Figure 5: Inequality trends

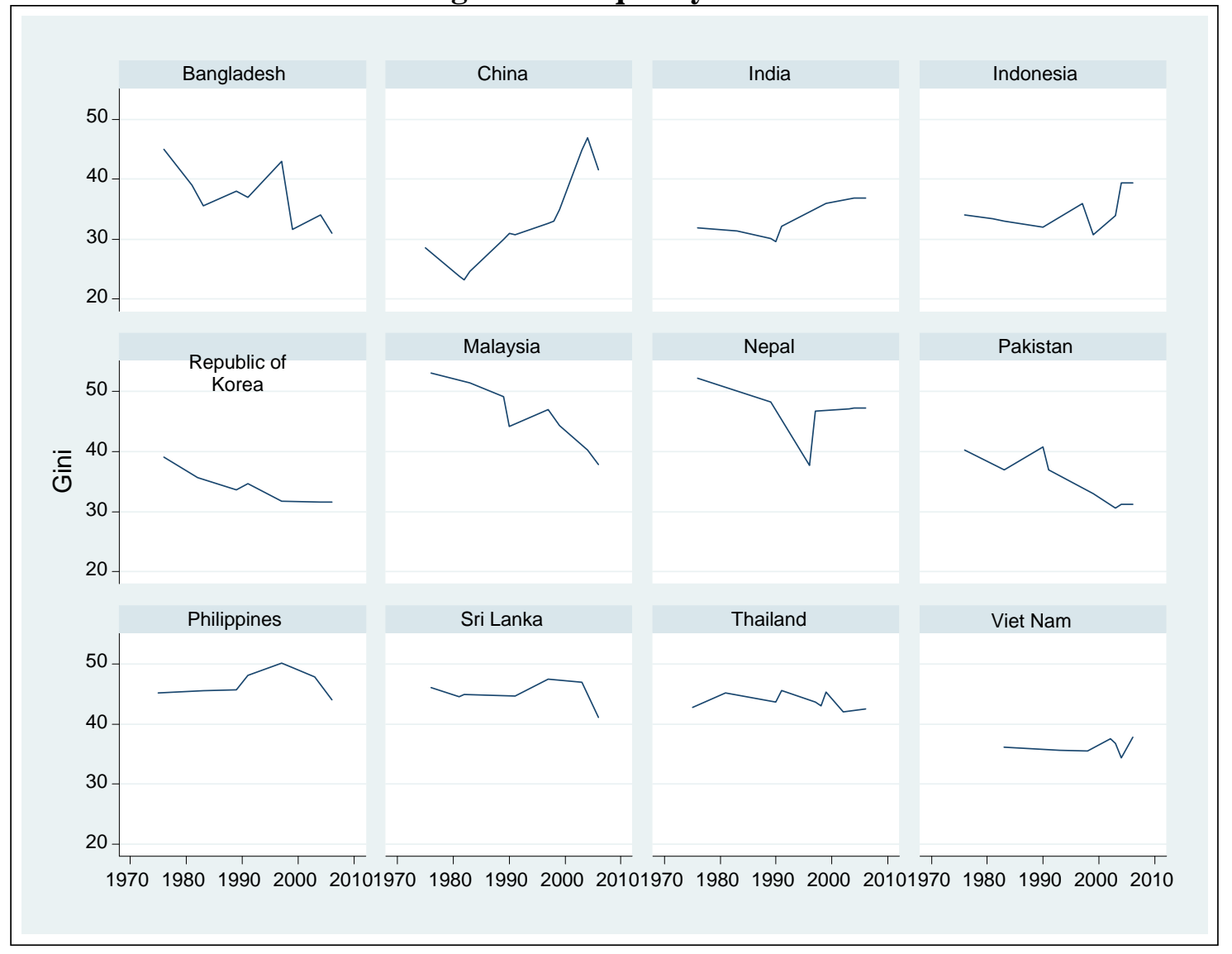


Figure 6: Trends in trade openness and trade liberalization

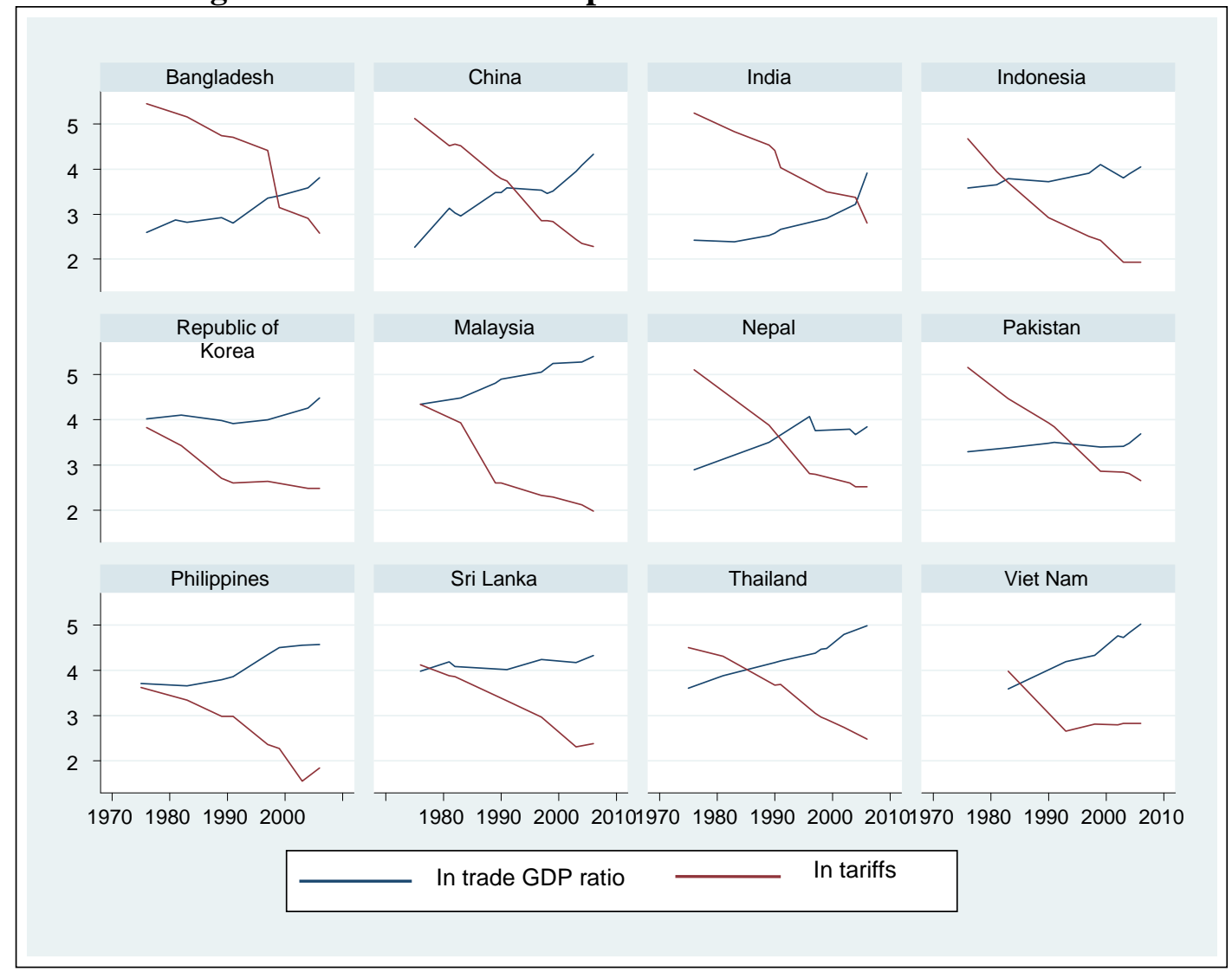


Figure 7: Trends in infrastructure

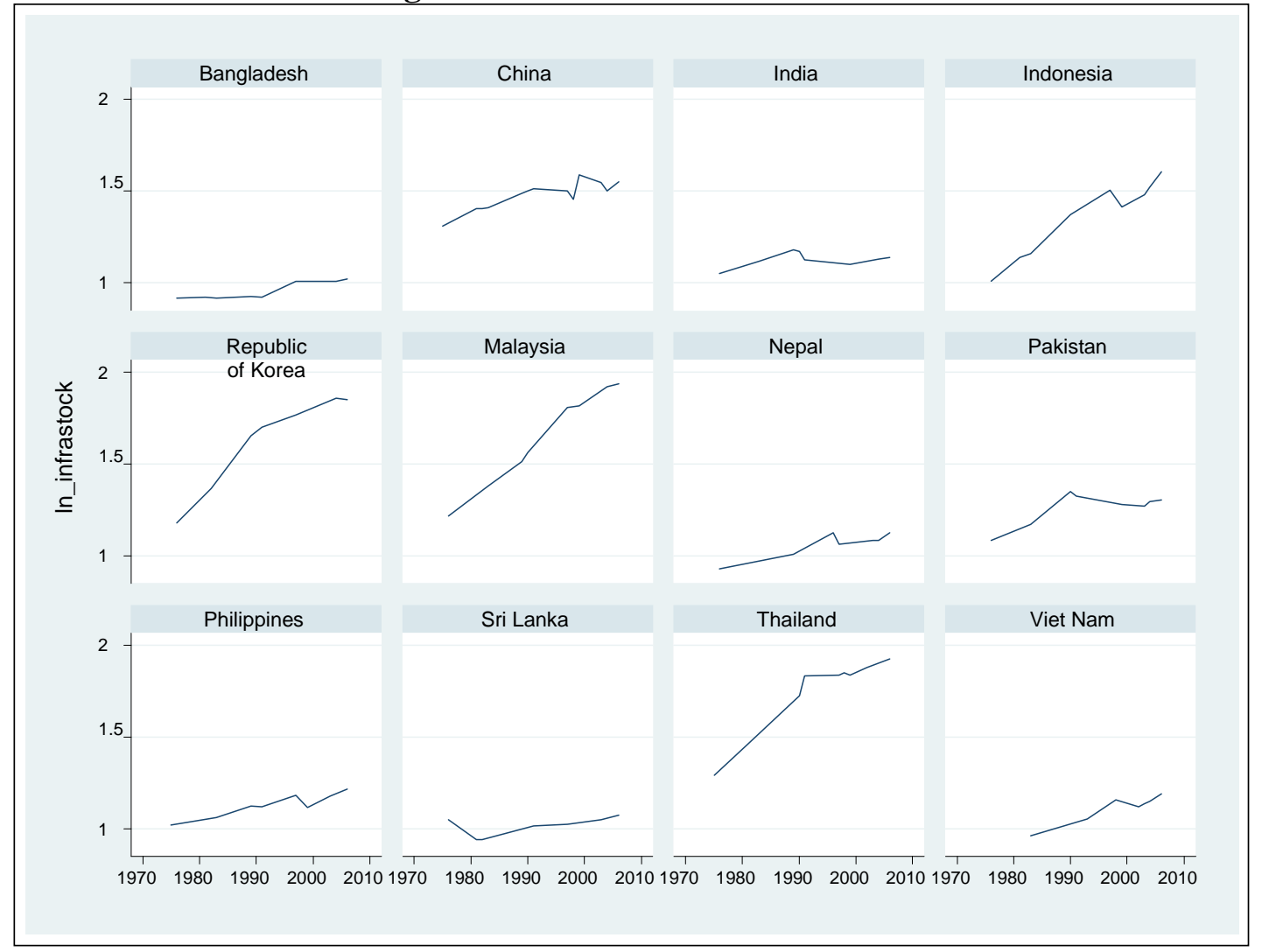

First, the larger countries of Asia and the Pacific have witnessed an absolute rise in inequality over time (figure 5). China, for example, witnessed a steep rise in inequality, increased from 28.60 per cent in 1975 to 41.50 per cent in 2006 with a low of 23.20 per cent in 1982 . Bangladesh, on the other, witnessed a fall in inequality from 45.00 per cent in 1976 to 31.00 per cent in 2006, with a rise of inequality at 43 per cent in 1997. Thus, cross-country variability in the inequality is very important when we attempt to understand its consequences on trade and infrastructure.

Second, Asian and Pacific countries have witnessed a rise in trade liberalization (a fall in import tariffs) and trade openness (a rise in trade-GDP ratios), but the trends vary across countries (figure 6). For example, the Republic of Korea, Malaysia and the Philippines have witnessed parallel movements of trade liberalization and trade openness from the initial years, whereas others have witnessed a mixed result showing relatively higher distortions in the initial years. Those countries that adopted an export-led growth strategy have also been associated with drastic trade liberalization in terms of tariff cuts. Nonetheless, trade liberalization and trade openness are uncontested and documented in the development of Asian and Pacific countries.

Third, infrastructure disparity is rampant across countries in Asia and the Pacific, and the stock of infrastructure in those countries is not too large (figure 7). For example, China, the Republic of Korea, Indonesia and Malaysia have higher infrastructure stocks than others. Starting 
with a low base, Indonesia appears to have progressed much faster than the other countries in raising its infrastructure stocks. Therefore, change in infrastructure stock is one of the important factors affecting the long-term behaviour of the Asian and Pacific countries.

\section{Trade, infrastructure and inequality: The empirical relationship}

This section begins by exploring whether or not trade openness reduces inequality with reference to equation (2). The estimated results are presented in table 3 . The following observations are worth noting.

The panel being considering has a very strong correlation between per capita income and the openness index as revealed by the trade ratio to GDP. Thus, it will create a definite problem if both of these variables are taken together. However, even if we do not take per capita income, it might well influence the result through a fixed-effect regression, where country size and strength are important determinants. This is also important for a random-effect regression, but there are factors that may be beyond the control of individual countries and may thus affect its performance; for example, a global macroeconomic scenario or policies taken in large countries. A similar situation holds for the population variable taken here (see annex). Hence, the regressions reported here try to avoid the obvious multi-collinearity problem. Also, the data structure shows non-linearity so that double log regressions give better results than non-transformed variable-based regressions.

The other important point to note is that in all regressions the classical linear regression is dominated by either the random-effect or fixed-effect model, as revealed by the Breusch-Pagan Lagrange Multiplier test. Hence, the ordinary regression results are not reported here because they are not statistically tenable. However, finally it is reported whether a random-effect or a fixed-effect regression model holds as revealed by the Hausman test.

Next, the authors have attempted to test the persistence of either inequality or openness among the countries in the panel through a dynamic panel analysis. This system dynamic panel data analysis, following Arrelano-Bover/Bover-Bond methodology, also solves the endogeneity problem that is a major headache in any dynamic panel analysis. The system dynamic panel approach improves upon the difference dynamic panel analysis by Arrellano and Bond by reducing the finite sample bias, thereby increasing the efficiency of the estimators. The authors have attempted to maintain some parity between the static panel analysis and the dynamic panel analysis, so that one may judge the persistence theory in the light of an ordinary static panel outcome. 
Table 3: Inequality, trade and infrastructure: Baseline regression results (Dependent variable $=$ inequality)

\begin{tabular}{|c|c|c|c|}
\hline $\begin{array}{c}\text { Variables } \\
\text { (1) }\end{array}$ & $\begin{array}{l}\text { In Gini } \\
(2)\end{array}$ & $\begin{array}{c}\text { In Gini } \\
\text { (3) }\end{array}$ & $\begin{array}{c}\text { In Gini } \\
(4)\end{array}$ \\
\hline Trade openness (in trade GDP) & $\begin{array}{l}0.145^{c} \\
(0.042)\end{array}$ & $\begin{array}{l}0.107^{b} \\
(0.028)\end{array}$ & \\
\hline Infrastructure stock (in infrastock) & $\begin{array}{c}.020 \\
(0.100)\end{array}$ & $\begin{array}{l}-0.126^{\mathrm{a}} \\
(0 . .076)\end{array}$ & $\begin{array}{l}-0.038^{c} \\
(0.091)\end{array}$ \\
\hline Infrastructure quality (in tdloss) & $\begin{array}{l}0.086^{\mathrm{a}} \\
(0.034)\end{array}$ & $\begin{array}{l}0.055^{\mathrm{a}} \\
(0.032)\end{array}$ & $\begin{array}{l}0.059^{b} \\
(0.027)\end{array}$ \\
\hline Per capita income (in pc GDP) & & & $\begin{array}{l}0.278^{\mathrm{c}} \\
(0.032)\end{array}$ \\
\hline Land (in land) & $\begin{array}{l}0.228^{b} \\
(0.095)\end{array}$ & & $\begin{array}{l}0.317^{\mathrm{c}} \\
(0.068)\end{array}$ \\
\hline Constant & & $\begin{array}{l}3.265^{c} \\
(0.169)\end{array}$ & \\
\hline Observations & 120 & 120 & 120 \\
\hline Adjusted R-squared & 0.659 & $\begin{array}{l}0.331 \text { (Non- } \\
\text { adjusted) }\end{array}$ & 0.784 \\
\hline Country fixed-effects & Yes & No & Yes \\
\hline Model & OLS & GLS & OLS \\
\hline Breusch and Pagan LM test, chi2 (p-value) & $\begin{array}{l}59.46^{\mathrm{c}} \\
(0.000)\end{array}$ & $\begin{array}{c}66.70^{\mathrm{c}} \\
(0.000)\end{array}$ & $\begin{array}{l}142.44^{\mathrm{c}} \\
(0.000)\end{array}$ \\
\hline Hausman test, chi2 (p-value) & $7.91^{\mathrm{c}}(0.095)$ & $2.15(0.542)$ & $12.00^{\mathrm{b}}(0.017)$ \\
\hline \multirow[t]{2}{*}{ Fixed-effect coefficients } & $\begin{array}{c}\text { Max }=3.229^{c} \\
\text { (Indonesia) }\end{array}$ & & $\begin{array}{l}\text { Max }=2.186^{c} \\
\text { (Singapore) }\end{array}$ \\
\hline & $\begin{array}{c}\text { Min }=2.284^{\mathrm{c}} \\
\text { (Singapore) }\end{array}$ & & $\begin{array}{c}\text { Min }=1.210^{\mathrm{b}} \\
\quad \text { (Malaysia) }\end{array}$ \\
\hline
\end{tabular}

Note: Standard errors in parentheses.

${ }^{\mathrm{a}} \mathrm{p}<0.1,{ }^{\mathrm{b}} \mathrm{p}<0.05,{ }^{\mathrm{c}} \mathrm{p}<0.01$.

First, the Breusch-Pagan statistic clearly establishes that panel regressions are better than the corresponding pooled classical regressions. Only regression in column 3 of table 3 shows that the GLS-based random-effect model dominates the fixed-effect model. In the other cases, the fixedeffect model is the relevant one.

Second, as explained above, trade openness and per capita GDP could not be taken together for multi-collinearity. In the regression given by column 2, trade GDP in logarithmic terms has a significant positive effect on inequality. Thus, more openness leads to higher inequality, which supports the theory of gains for skilled labour after countries become more integrated with the global economy. A better quality of infrastructure with lower T\&D loss reduces inequality, although geographically larger countries lead to higher inequality. Infrastructure does not have any significant effect on inequality in Asian and Pacific countries. The individual effects were also calculated; they 
more or less indicate that countries have individual effects (maximum and minimum values are given) that show considerable positive impact on inequality even in the absence of other variables in the regression.

Third, column 3 shows similar results as in the first regression, except that this regression shows that (a) countries do not have any specific individual effect, and (b) better infrastructure reduces inequality. Here, the constant value again plays an important positive and significant role. However, in this case, global policies play a more important role than country-specific policies. The $\mathrm{R}^{2}$ value is much lower in this case than in the other cases. As expected, the per capita GDP has a similar impact as that in trade openness and, since they move together, inequality is certainly exacerbated as countries have more openness.

Fourth, infrastructure stock is significant in two of the three models. The estimated coefficients of infrastructure stock clearly indicate that infrastructure improvement reduces income inequality, all other things being equal. Controlling for country fixed-effects, 1 per cent improvement in infrastructure would lead to a fall of 4 per cent to 12.6 per cent in inequality for Asian and Pacific countries. A rise in infrastructure stock helps countries to increase income in the medium to long term, thus generating scope for redistribution of income, both within and across countries.

At the same time, the quality of infrastructure is very important. All the estimated coefficients of the variable infrastructure quality are significant at the 5 per cent- 10 per cent levels. The estimated coefficients of infrastructure quality (represented here by transmission and distribution loss of electricity) indicate that quality deterioration of infrastructure facilities (e.g., a rise in transmission and distribution loss of electricity) would lead to a rise in income inequality. It is intuitive that higher losses in transmission and distribution of electricity lead to less availability of electricity for users, causing a disadvantage for the poorer income groups. This may well lead to inequality in income distribution as the latter is disadvantaged with regard to one crucial input in the production of goods and services.

Fifth, the estimates also suggest that inequality is high in land-endowed countries (per capita land density) and in countries with higher per capita income in the Asia-Pacific region.

Next, the question of whether or not there is a reverse relationship from income inequality to trade openness is explored with reference to equation (3). Here, trade openness is taken as a dependent variable, with income inequality, infrastructure stocks and infrastructure quality, and other control variables taken as independent variables. The estimated results are presented in table 4, columns (2) to (5). The following observations are worth noting. 
Table 4: Trade, Inequality and infrastructure: Baseline regression results (Dependent variable $=$ trade openness)

\begin{tabular}{|c|c|c|c|c|}
\hline $\begin{array}{l}\text { Variables } \\
\text { (1) }\end{array}$ & $\begin{array}{c}\text { In trade GDP } \\
(2)\end{array}$ & $\begin{array}{c}\text { In trade GDP } \\
(3)\end{array}$ & $\begin{array}{c}\text { In trade GDP } \\
(4)\end{array}$ & $\begin{array}{c}\text { In trade GDP } \\
(5)\end{array}$ \\
\hline $\begin{array}{l}\text { Income inequality (in } \\
\text { Gini) }\end{array}$ & $\begin{array}{l}0.443^{b} \\
(0.207)\end{array}$ & $\begin{array}{l}-0.438^{\mathrm{a}} \\
(0.262)\end{array}$ & $\begin{array}{c}0.101 \\
(0.261)\end{array}$ & $\begin{array}{l}-0.106 \\
(0.239)\end{array}$ \\
\hline $\begin{array}{l}\text { Infrastructure stock (in } \\
\text { infrastock) }\end{array}$ & $\begin{array}{c}0.256 \\
(0.196)\end{array}$ & $\begin{array}{l}-0.462 \\
(0.287)\end{array}$ & $\begin{array}{l}-0.582^{\mathrm{b}} \\
(0.260)\end{array}$ & $\begin{array}{l}-0.422^{\mathrm{a}} \\
(0.254)\end{array}$ \\
\hline $\begin{array}{l}\text { Infrastructure quality (in } \\
\text { tdloss) }\end{array}$ & $\begin{array}{l}-0.861 \\
(0.075)\end{array}$ & $\begin{array}{l}-0.052 \\
(0.081)\end{array}$ & $\begin{array}{l}-0.069 \\
(0.073)\end{array}$ & $\begin{array}{l}-0.047 \\
(0.071)\end{array}$ \\
\hline $\begin{array}{l}\text { Per capita income (in pc } \\
\text { GDP) }\end{array}$ & & $\begin{array}{l}0.722^{\mathrm{c}} \\
(0.066)\end{array}$ & $\begin{array}{l}0.391^{\mathrm{c}} \\
(0.110)\end{array}$ & $\begin{array}{c}0.403^{c} \\
(0.104)\end{array}$ \\
\hline $\begin{array}{l}\text { Land } \\
\text { (in land) }\end{array}$ & & & $\begin{array}{l}-0.974^{\mathrm{c}} \\
(0.197)\end{array}$ & \\
\hline $\begin{array}{l}\text { Trade liberalization (in } \\
\text { tariffs) }\end{array}$ & $\begin{array}{l}-0.312^{\mathrm{c}} \\
(0.036)\end{array}$ & & & $\begin{array}{l}-0.223^{\mathrm{c}} \\
(0.041)\end{array}$ \\
\hline Observations & 120 & 120 & 120 & 120 \\
\hline Adjusted R-squared & 0.943 & 0.936 & 0.948 & 0.950 \\
\hline Country fixed-effects & Yes & Yes & Yes & Yes \\
\hline Model & OLS & OLS & OLS & OLS \\
\hline $\begin{array}{l}\text { Breusch and Pagan LM } \\
\text { test, chi2 (p-value) }\end{array}$ & $\begin{array}{l}82.41^{\mathrm{c}} \\
(0.000)\end{array}$ & $\begin{array}{l}102.80^{\mathrm{c}} \\
(0.000)\end{array}$ & $104.44^{\mathrm{c}}(0.000)$ & $\begin{array}{l}85.70^{\mathrm{c}} \\
(0.000)\end{array}$ \\
\hline $\begin{array}{l}\text { Hausman test, chi2 (p- } \\
\text { value) }\end{array}$ & $12.22^{\mathrm{b}}(0.016)$ & $11.87^{\mathrm{b}}(0.018)$ & $32.23^{\mathrm{c}}(0.000)$ & $10.32^{\mathrm{a}}(0.067)$ \\
\hline Fixed-effect coefficients & $\begin{array}{c}\text { Max }=3.856^{\mathrm{c}} \\
(\text { Malaysia) } \\
\text { Min = 2.526 } \\
\text { (India) }\end{array}$ & $\begin{array}{c}\text { Max }=2.434^{\mathrm{a}} \\
(\text { Viet Nam) } \\
\text { Min = 0.101 } \\
\text { (Rep. of Korea) }\end{array}$ & $\begin{array}{c}\text { Max }=5.276^{c} \\
\text { (Malaysia) } \\
\text { Min = 0.798 } \\
\text { (Hong Kong, } \\
\text { China) } \\
\end{array}$ & $\begin{array}{c}\text { Max }=3.732^{\mathrm{c}} \\
(\text { Viet Nam) } \\
\text { Min }=2.312^{\mathrm{b}} \\
\text { (Rep. of Korea) }\end{array}$ \\
\hline
\end{tabular}

Note: Robust standard errors in parentheses.

${ }^{\mathrm{a}} \mathrm{p}<0.1,{ }^{\mathrm{b}} \mathrm{p}<0.05,{ }^{\mathrm{c}} \mathrm{p}<0.01$.

First, all regression models again show the dominance of panel regression over classical pooled regression. In addition, all the panel regressions show strong country-specific individual effects. Trade liberalization as measured by tariff levels strongly influences trade openness in regressions expressed in columns 2 and 5 . In fact, the first regression shows a very strong inverse relation between tariff reduction and higher trade levels across Asia and the Pacific. Also, reverse causality between trade and inequality appears to work here, since more unequal nations influence trade positively. This regression does not take per capita income as a regressor since it tends to influence other explanatory variables strongly. However, infrastructure stock as well as quality does not appear to have any significant influence on trade. The country-specific effect does matter significantly with maximum effect being shown for Malaysia and minimum effect for India. 
Incidentally, Malaysia is one of the more open economies and it is not surprising that apart from tariffs, this country has adopted specific pro-trade policies to boost its trade.

Second, once the per capita income is introduced, it tends to capture most of the effects on trade. In columns 3 to 5 of table 4, all regression models show that the richer the country, the higher the trade value. Tariffs play an important role and they always promote trade when reduced. However, the per capita income variable has a strong correlation with infrastructure variables, so it is not surprising that infrastructure stock appears to have retarded the trade of nations across the Asia-Pacific region. Under the circumstances, calculating the influence of infrastructure stock and quality in the absence of per capita income as a regressor, as is done in column 2, appears reasonable. However, infrastructure does not appear to play any significant role in increasing openness of a country; of greater importance is the impact of tariffs, which boost trade with or without infrastructural development. This is an important finding.

Third, a significant positive influence of country-specific policies on trade openness apart from the influence of tariffs is again found. It is also not surprising that Malaysia and Viet Nam stand out as the most important countries with regard to having pursued individual policies vigorously. Clearly, tariffs, inequality and per capita income are found to be common variables significantly influencing trade, but it is also asserted that there are country-specific policies that matter for the trade openness. However, not only are the richer countries more open - the more economically unequal nations also influence trade across countries in the Asian and Pacific region at different levels of development. In fact, this is consistent with other studies that show trade variables such as exports are influenced by different factors, e.g., the real exchange rate and world demand (Marjit and Raychaudhuri, 1997). Because this study focused on the role of infrastructure, in order to avoid problems such as multi-collinearity real exchange rates and world income were not taken into consideration; they are country-specific and show up in the significant fixed-effect coefficients.

With regard to robustness checks (as explained in section B), in order to rule out the possibility of endogeneity in equations (2) and (3) above, a dynamic GMM estimator (systemGMM) was used to analyse changes across countries and over time. ${ }^{12}$ Also, the Arellano-Bond estimates presented in tables 5 and 6 remove the weak instrumental variables and poor efficiency problems since they utilize more moment conditions. Table 5 provides system-GMM estimates when the dependent variable is income inequality, whereas table 6 presents the similar estimates when trade openness is the dependent variable. To test the appropriateness of the instruments used, the Sargan J statistics of over-identifying restrictions in tables 5 and 6 were used. The J- statistics show that the applied instruments are valid. It should also be noted that the authors attempted to maintain some parity with the static and dynamic panel estimation, since that makes it easier to compare and contrast the results obtained.

\footnotetext{
${ }^{12}$ Refer, for example, Arellano and Bover (1995) and Blundell and Bond (1998).
} 
Table 5: Arellano-Bover Dynamic Panel-data estimation (system GMM): Dependent variable equals inequality (in Gini)

\begin{tabular}{lccc}
\hline Variables & Coefficient & S.E. & t-Statistic \\
\hline Inequality (in Gini) & & & \\
$\quad$ L1 & 0.120 & 0.122 & 0.978 \\
L2 & $0.1799^{\mathrm{b}}$ & 0.089 & 2.005 \\
Trade openness (in trade GDP) & -0.022 & 0.056 & -0.406 \\
Infrastructure stock (in infrastock) & -0.060 & 0.076 & 0.780 \\
Infrastructure quality (in tdloss) & -0.041 & 0.039 & -1.035 \\
& 6.164 & & \\
Hansen Sargan J-statistic, chi2 (p-value) & $(0.723)$ & & \\
Observations & & 78 & \\
Instrument rank & & 14 & \\
\hline Note: Dynamic panel counts White period instrument weighting matrix, White period \\
standard errors and co-variance (d.f. corrected). The estimation uses \\
$\quad$ deviathogonal \\
$\quad$ b ${ }^{\text {p }<0.05,}$ \\
L1 and L2 equal lags 1 and 2, respectively.
\end{tabular}

Table 6: Arellano-Bover Dynamic Panel-data estimation (system GMM): Dependent variable equals trade openness (in trade GDP)

\begin{tabular}{lccc}
\hline Variable & Coefficient & S. E. & t-Statistic \\
\hline Trade openness (in trade GDP) & $0.373^{\mathrm{b}}$ & 0.142 & 2.627 \\
$\quad$ L1 & 0.101 & 0.100 & 1.015 \\
$\quad$ L2 & $0.333^{*}$ & 0.192 & 1.739 \\
Inequality (in Gini) & $-0.157^{\mathrm{a}}$ & 0.049 & -3.180 \\
Trade liberalization (in tariffs) & 0.452 & 0.701 & 0.645 \\
Infrastructure stock (in infrastock) & -0.085 & 0.215 & -0.393 \\
Infrastructure quality (in tdloss) & 9.830 & & \\
& $(0.198)$ & & \\
Hansen Sargan J-statistic, chi2 (p-value) & & & \\
Observations & & & \\
Instrument rank & & & \\
\hline Note: Dynamic panel counts White period instrument weighting matrix, and White \\
period standard errors and co-variance (d.f. corrected). The method uses orthogonal \\
deviation. \\
a p $<0.01$, ${ }^{\mathrm{b}} \mathrm{p}<0.05$ \\
L1 and L2 equal lags 1 and 2, respectively.
\end{tabular}

It is apparent that past inequality significantly determines the present level of inequality (two periods of lagged inequality are statistically significant), but trade openness together with all the infrastructure variables have little influence on the movement of inequality in countries over time. In support of the previous findings (table 3), system-GMM estimates suggest persistence of inequality, since the initial level of inequality appears to be the only instrument that matters in the evolution of income inequality over space and time. 
In contrast, one period of lagged values of trade openness significantly influences the current trade to GDP ratio, again showing persistence; however, unlike in the earlier case for inequality, tariff liberalization together with inequality play a significant role in trade openness. This again supports the static panel result. Thus, although a more open economy does not significantly reduce inequality, the reverse is not true. However, infrastructure improvement is again not an important factor for the evolution of more trade and less inequality in the economy.

\section{E. Conclusion}

The foregoing analysis provides a synoptic view of the role of infrastructure in economic growth and income inequality as well as international trade of countries in Asia and the Pacific. The point that is emphasized throughout this paper is that infrastructure mainly appears as a complementary factor in the standard literature. As a result, the authors have discussed the role of infrastructure in a somewhat compartmentalized manner. In the existing literature on the subject, although not comprehensive or specific in terms of the theme under consideration in this paper the positive impact of infrastructure on growth is proved through growth regressions; however, the important point to note is that infrastructure (or public capital) is a factor whose efficiency is as equally important as its quantity. Possibly this applies to all factors of production, but for infrastructure this is emphasized time and again. The developing countries unambiguously show this positive impact, unlike some of the developed countries.

Unfortunately, most of this work does not address either trade or income distribution issues. The literature that deals with inclusive growth and poverty highlights the fact that accessibility to infrastructure, like rural roads or electricity, does not benefit the poor much. Hence, the result may be an unintended widening of income disparity. The authors suggest direct targeted policy intervention in this case.

The literature on infrastructure's role in growth or inclusive growth rarely discusses the trade issues at the same time. Given the $2 \times 2 \times 2$ structure of trade models, the role of infrastructure is discussed mainly as a trade-enabling or facilitating device as well as a facet that could reduce trade costs if used more efficiently. The existing literature on infrastructure and trade more or less concentrates on these two themes, without giving much attention to growth or inclusive growth in an integrated framework.

Going through the above literature, it is clear that one needs a study that looks at the individual causalities in an integrated framework and discusses the role of infrastructure in growth and income distribution in an open economy framework. This would look at infrastructure, in terms of both quantity and quality, as an important causal factor promoting trade and inclusive growth in the economy. The panel regressions carried out here fulfill this gap to some extent. However, it must be noted that, country-specific studies are essential to gaining a better understanding of this issue, as is clearly revealed by the regression results.

In the panel regressions detailed in this paper, both infrastructure quantity and quality are found to affect inequality. However, the same is not true for trade. Infrastructure is overshadowed by trade liberalization measures when it comes to increasing trade in an economy. In addition, 
country-specific policies are shown to be significant determinants of both trade and inequality, apart from infrastructure development. Thus, for trade, it may be the exchange rate or foreign exchange management policies as well policies of protection to specific goods. For inequality, it may be some directly-targeted poverty alleviation policies. Therefore, although infrastructure development may reduce inequality, this may be not so important for raising trade volumes. Also, persistence is important for both inequality and trade, pointing to the fact that initial levels matter and this cannot be overshadowed immediately by a sudden change in infrastructure or country-specific policy designs. This is the message that comes out from the unbalanced panel regressions, spanning 1975 to 2006, which were run for 14 countries at different levels of development in the Asia-Pacific region.

Infrastructure development unambiguously decreases inequality, but its effect on trade is not particularly significant. At the same time, there is no substitute for country-specific studies in understanding such linkages, since such country-specific policies together with infrastructure development are significant determinants in achieving higher trade accompanied by lower income inequality. 


\section{References}

Acharyya, R (2008). “International trade, poverty, and income inequality: The Indian experience during the reform period 1985-199”, in Asian Development Bank (ed.), Trade Policy, Industrial Performance, and Private Sector Development in India; pp. 97-140. Oxford University Press, New Delhi.

Ali, I. and E. M. Pernia (2003). “Infrastructure and poverty reduction - what is the connection?” ERD Policy Brief No. 13. Asian Development Bank, Manila.

Anderson, J. E. and E. van Wincoop (2004). “Trade costs”, Journal of Economic Literature, vol. XLII, No. 3; pp. 691-751.

Arellano, M., and O. Bover (1995). "Another look at the instrumental variable estimation of error component models”, Journal of Econometrics, vol. 68, No. 1, pp. 29-51.

Arellano, M. and S. Bond (1991). "Some tests of specification for panel data: Monte Carlo evidence and an application to employment equations”, Review of Economics Studies, vol. 58, No. 2; pp. 277-297.

Aschauer, D. A. (1998). "Public capital and economic growth: issues of quantity, finance and efficiency”, Working Paper No. 233, Jerome Levy Economic Institute of Bard College, New York

(1989). “Is public expenditure productive?” Journal of Monetary Economics, vol. 23; pp. 177-200.

Asian Development Bank (2007). Key Indicators of Developing Asian and Pacific Countries. Manila.

Barro, R. J. (1990). “Government spending in a simple model of endogenous growth”, Journal of Political Economy, vol. 98, No. 5; pp. S102- S125.

(1991). "Economic growth in a cross-section of countries", Quarterly Journal of Economics, vol. 106, pp. 407-443.

Barnes, D. F. and H. P. Binswanger (1986). "Impact of rural electrification and infrastructure on agricultural changes: 1966-1980”, Economic and Political Weekly, vol. 21, No. 1.

Bhagwati, J. N. and T. N. Srinivasan (2003). "Trade and poverty in the poor countries". Available online at www.econ.yale.edu/ srinivas/trade_poverty.pdf.

Binswanger, H. P., S. R. Khandker and M. R. Rosenzweig (1989). "How infrastructure and financial institutions affect agriculture output and investment in India”, Policy Planning and Research Working Paper No. 163. World Bank, Washington, D.C.

Blundell, R. and S. Bond (1998). "Initial conditions and moment restrictions in dynamic panel data models”. Journal of Econometrics, vol. 87, No. 1; pp. 115-143.

Brenneman, A. and M. Kerf (2002). "Infrastructure and poverty linkages: A literature review" (mimeograph). World Bank, Washington, D.C.

Briceño-Garmendia, C., A. Estache and N. Shafik (2004). "Infrastructure services in developing countries: Access, quality, costs and policy reform”, Working Paper No. 3468. World Bank, Washington D.C. 
Brooks, D. H. and D. Hummels (eds.) (2009). Infrastructure's Role in Reducing Asia's Trade Costs: Building for Trade. Edward Elgar Publishing, Cheltenham, United Kingdom and Massachusetts, United States, and Asian Development Bank Institute, Tokyo.

Calderón, C., and L. Servén (2005). "The effects of infrastructure development on growth and income distribution”, World Bank Policy Research Working Paper 3643. World Bank, Washington, D.C.

Campano, F. and D. Salvatore (2007). “Economic Development and Income Distribution” Journal of Policy Modeling, vol. 29; pp. 553-566.

Canning, D. (2006), “A database of world infrastructure stocks, 1950-95”, World Bank Policy Research Working Paper No. 1929. World Bank, Washington D.C.

Datt, G. and M. Ravallion (2002). "Is India's economic growth leaving the poor behind?” World Bank Policy Research Working Paper No. 2846. World Bank, Washington, D.C.

(1998). "Why have some Indian States done better than others at reducing poverty", Economica, vol. 65; pp. 257.

De, P. (2009a). "Empirical estimates of transportation costs: options for enhancing Asia's trade” in Douglas H. Brooks and David Hummels (eds.) Infrastructure's Role in Lowering Asia's Trade Costs: Building for Trade, Edward Elgar, Cheltenham, UK

De, P. (2009b). Asia Infrastructure Database (AID) Version 1.0, New Delhi.

(2007). "Impact of trade costs on trade: Empirical evidence from Asian countries”, in Trade Facilitation beyond the Multilateral Trade Negotiations: Regional Practices, Customs Valuation and Other Emerging Issues. United Nations Economic and Social Commission for Asia and the Pacific, Bangkok.

Deardorff, Alan V (2001a). "International Provision of Trade Services, Trade, and Fragmentation," Review of International Economics, vol. 9, No. 2, pp. 233-48.

Deardorff, Alan V. (2001b). “International Provision of Trade Services, Trade and Fragmentation”, Policy Research Working Paper No. 2548, World Bank, Washington, D.C..

Deninger, K. and J. Okidi (2003). "Growth and poverty reduction in Uganda, 1999-2000: Panel data evidence”, Development Policy Review, vol. 21, No. 4.

Edwards, S. (1997). “Trade policy, growth, and income distribution”, American Economic Review, vol. 87. No. 2; pp. 205-210.

ESCAP (2009). Asia-Pacific Trade and Investment Report 2009. Bangkok.

(2001). Reducing Disparities: Balanced Development of Urban and Rural Arears and Regions within the Countries of Asia and the Pacific, Bangkok.

Estache, A. (2006). "Infrastructure: A survey of recent and upcoming issues". World Bank, Washington D.C.

Fan, S. L., Zhang and X. Zhan (2002). Growth, inequality and poverty in China: The role of public investments”, Research Report 123. International Food Policy Research Institute, Washington, D.C.

Fedderke, J. W., P. Perkins, and J. M. Luiz (2006). "Infrastructural investment in long-run economic growth: South Africa 1875-2001”, World Development, vol. 34, No. 6; pp. 1037-1059. 
Ghosh, B. and P. De (2005). "Investigating the linkage between infrastructure and regional development: Era of planning to globalisation”, Journal of Asian Economics, vol. 15, No. 1; pp. 1023-1050.

Gourdon, J., N. Maystre, and J de Melo (2008). “Openness, inequality and poverty: Endowments matter”, The Journal of International Trade and Economic Development, vol. 17, No. 3; pp. 343-378.

Hulten, C. R. (1996). "Infrastructure capital and economic growth: How well you use it may be more important than how much you have”, NBER Working Paper No. 5847. National Bureau of Economic Research, New York.

Independent Evaluation Group (2008). The Welfare Impact of Rural Electrification: A Reassessment of the Costs and Benefits. World Bank, Washington, D.C.

Jacoby, H. (2000). “Access to rural markets and the benefits of rural roads”, The Economic Journal, vol. 110; pp. 713-737.

Khandker, S and G. Koolwal (2006). “Are pro-growth policies pro-poor?” (mimeograph). World Bank, Washington, D.C.

Khandker, S, Z. Bakht and G. Koolwald (2006). "The poverty impact of rural roads: Evidence from Bangladesh”, World Bank Policy Research Working Paper 3875. World Bank, Washington, D.C.

Levine, R and D. Renelt (1991). “A sensitivity analysis of cross-country growth regressions”, World Bank Policy Research Working Paper 609. World Bank, Washington, D.C.

Limao, N. and A. J. Venables (2001). "Infrastructure, geographical disadvantage, transport costs and trade.” World Bank Economic Review, vol. 15; pp. 451-479.

Marjit, S and A. Raychaudhuri (1997). India's Exports, Oxford University Press, New Delhi.

Munnell, A (1992)..'Infrastructure Investment and Economic Growth.'The Journal of Economic Perspectives, vol. 6, No. 4, pp. 189-198.

Organisation for Economic Co-operation and Development (2003). "Quantitative Assessment of the Benefits of Trade Facilitation”, TD/TC/WP(2003)31/FINAL. Paris.

Pinstrup-Andersen, P. and S. Shimokawa (2006). "Rural infrastructure and agricultural development”, paper presented at the World Bank ABCDE Conference, Tokyo.

Ravallion, M. and G., Datt (1999). "When is growth pro-poor? Evidence from diverse experiences of Indian States”, World Bank Policy Research Working Paper 2263. World Bank, Washington, D.C.

Raychaudhuri, A. and P. De (2010). "Trade in services in India: Way forward to reduce poverty and inequality”, in Andrew Stoler and others (eds.) (2009) Trade and Poverty Reduction in the Asia Pacific Region, Cambridge University Press, Australia.

Raychaudhuri, A. (2004). "Success and limits to land reforms for poverty alleviation: A case study of West Bengal in India”, background paper prepared for the World Bank Scaling-up Poverty Reduction Conference, Shanghai.

Rodríguez, F. (2006). "Have collapses in infrastructure spending led to cross-country divergence in per capita GDP?” Background paper prepared for the World Economic and Social Survey. United Nations Department of Economic and Social Affairs, New York. 
Roland-Holst, D. (2006). "Infrastructure as a catalyst for regional integration, growth, and economic convergence: Scenario analysis for Asia”, ERD Working Paper 91. Asian Development Bank, Manila.

Slaughter, M. J. (1997). "Per capita income convergence and the role of international trade", American Economic Review, vol. 87, No. 2; pp. 194-199.

Songco, J. (2002). "Do rural infrastructure investments benefit the poor? Evaluating linkages: A global view, a focus on Viet Nam”, World Bank, Washington, D.C.

Straub, S. (2008). "Infrastructure and development: A critical appraisal of the macro level literature”, World Bank Policy Research Working Paper 4590. World Bank, Washington, D.C.

Winters, L. A., N. McCulloch and A. McKay (2004). "Trade liberalization and poverty: The evidence so far”, Journal of Economic Literature, vol. XLII, pp. 72-115.

World Bank (1994). World Development Report, 1994. Washington, D.C. 


\section{Annex}

List of variables and sources

\begin{tabular}{|c|c|c|}
\hline Label & Content & Sources \\
\hline Inequality (INQ) & Gini coefficient & $\begin{array}{l}\text { UNU-WIDER World Income } \\
\text { Inequality Database, Version } \\
\text { 2.0c, May } 2008 \text { (UNU- } \\
\text { WIDER, 2008, and ADB, } \\
\text { 2007) }\end{array}$ \\
\hline Trade openness (TO) & $\begin{array}{l}\text { Trade (export and import) as } \\
\text { percentage of GDP (per cent) }\end{array}$ & $\begin{array}{l}\text { World Development } \\
\text { Indicators CD-ROM 2009, } \\
\text { (World Bank, 2009) }\end{array}$ \\
\hline Trade liberalization (TL) & Simple average tariff (per cent) & $\begin{array}{l}\text { World Trade Integrated } \\
\text { Solution (WITS) }\end{array}$ \\
\hline Infrastructure stock (IS) & $\begin{array}{l}\text { Infrastructure quantity, which is } \\
\text { summed over normalized indicators } \\
\text { such as (a) air freight transport } \\
\text { (million tons/km); (b) electric power } \\
\text { consumption (kWh per capita); (c) } \\
\text { fixed line and mobile phone } \\
\text { subscribers (per } 1,000 \text { people); (d) } \\
\text { households with television } \\
\text { (percentage of total households); (e) } \\
\text { railway lines (km per } 1,000 \mathrm{~km}^{2} \text { of } \\
\text { geographical area); (f) roads, (km per } \\
1,000 \mathrm{~km}^{2} \text { of geographical area); and } \\
\text { (g) personal computers (per } 1,000 \\
\text { people). }\end{array}$ & $\begin{array}{l}\text { World Development Indicators } \\
\text { CD-ROM 2009, World Bank } \\
\text { (2009), and Asia Infrastructure } \\
\text { Database Version } 1.0 \text { (AID), } \\
\text { (De, 2009b) }\end{array}$ \\
\hline Infrastructure quality (IQ) & $\begin{array}{l}\text { Electric power transmission and } \\
\text { distribution losses (percentage of } \\
\text { output) }\end{array}$ & \\
\hline Per capita income (PCI) & GDP per capita (constant 2000 US\$) & \multirow{4}{*}{$\begin{array}{l}\text { World Development } \\
\text { Indicators } 2009 \text { online } \\
\text { database (World Bank, 2009). }\end{array}$} \\
\hline Geography (Land) & Per capita land availability $\left(\mathrm{km}^{2}\right)$ & \\
\hline Inflation (Inf) & GDP deflator (annual percentage) & \\
\hline Population (Pop) & $\begin{array}{l}\text { Working population (population ages } \\
15-64 \text {, percentage of total population) }\end{array}$ & \\
\hline
\end{tabular}

